Article

KARIM, M. ${ }^{1}$

JABEEN, K. ${ }^{*}$

IQBAL, S. ${ }^{1}$

JAVAID, A. ${ }^{2}$

\section{BIOEFFicACy OF A CoMmon WeEd Datura metel Against Colletotrichum gloeosporioides}

\section{Bioeficácia da Planta Datura metel contra Colletotrichum gloeosporioides}

* Corresponding author:

<khajista_1@hotmail.com>

Received: May 31, 2016

Approved: July 25, 2016

Planta Daninha 2017; v35:e017164676
ABSTRACT - Mango (Mangifera indica) is one of the most important trees grown mainly in the tropical and subtropical countries. Anthracnose disease caused by Colletotrichum gloeosporioides, is the most damaging disease causing reduction of flower set and yield losses in mango. The present study was designed to evaluate antifungal activity of Datura metel extracts against C. gloeosporioides. Extracts ( $1 \%$ to $3 \%$ ) of different parts of $D$. metel viz. leaves, seeds and roots were assessed for their antifungal potential. Methanolic seed extract of $D$. metel depicted the highest antifungal potential against the test fungus. All the applied concentrations effectively reduced growth of the test fungus. However, $1.5 \%$ conc. of methanolic seeds extract showed maximum reduction ( $80 \%$ ) in comparison with control. This extract was further subjected to fractionation using various organic solvents viz. $n$-hexane, chloroform, ethyl acetate and $n$-butanol. Chloroform fraction was proved to be the best for the inhibition of the target fungus that was analyzed by GC-MS and various bioactive constituents like $n$-hexadecanoic acid, phytol, octadecanoic acid, oleic acid, o-xylene and cyclohexanol were identified.

Keywords: antifungal, GC-MS, methanolic extracts, phytochemical analysis.

RESUMO - A mangueira (Mangifera indica) é uma das árvores mais importantes do mundo, cultivadas principalmente nos países tropicais e subtropicais. A antracnose, causada pelo fungo Colletotrichum gloeosporioides ,é a doença mais prejudicial, que causa a redução do número de flores e perdas de rendimento da manga. O presente estudo foi desenvolvido para avaliar a atividade antifúngica de extratos de Datura metel contra C. gloeosporioides. Extratos (1\% a 3\%) de diferentes partes de $\boldsymbol{D}$. metel viz. folhas, sementes e raizes foram avaliados quanto ao potencial antifúngico. O extrato metanólico de sementes de $\boldsymbol{D}$. metel apresentou o maior potencial antifúngico contra o fungo de teste. Todas as concentrações aplicadas reduziram com eficácia o crescimento do fungo de teste. No entanto, o extrato metanólico de sementes na concentração de 1,5\% apresentou redução máxima (80\%) em relação ao controle. Este extrato foi ainda submetido a fraccionamento utilizando vários solventes orgânicos viz. $\boldsymbol{n}$-hexano, clorofórmio, acetato de etila e n-butanol. A fração de clorofórmio mostrou ser a melhor para a inibição do fungo-alvo, após análise por meio de GC-MS, e foram identificados vários constituintes bioativos, por exemplo, ácido $\boldsymbol{n}$-hexadecanóico, fitol, ácido octadecanóico, ácido oleico, o-xileno e ciclo hexanol.

Palavras-chave: antifúngico, GC-MS, extratos metanólicos, análise fitoquímica.

1 Department of Botany, Lahore College for Women University, Jail Road, Lahore, Pakistan; ${ }^{2}$ Institute of Agricultural Sciences, University of the Punjab, Lahore, Pakistan. 


\section{INTRODUCTION}

Mango is one of the most delicious fruits in the world and it has attained a special position in the line of delightful fruits; it has significant nutritive and therapeutic elements (Tahir et al., 2012). Pakistan ranks fourth in terms of mango production worldwide (Ghafoor et al., 2010). Research studies on mango shows the presence of many nutritional contents viz. crude proteins, carbohydrates and vitamins (Sarkiyayi et al., 2013). Mango crops are damaged by many pre- and post-harvest diseases, including anthracnose, which is caused by Colletotrichum gloeosporioides (Pandey et al., 2012). Under warm and humid conditions, anthracnose is one of the most damaging and persistent diseases, and it causes mass losses in mango fields (Saju et al., 2013). This fungus contains various pectinolytic enzymes (polygalacturonase trans eliminase, pectin trans eliminase, polygalacturonase, pectin methyl esterase) and cellulolytic enzymes (cellulase) which are responsible for its pathogenicity (Jat et al., 2013). To control this disease, synthetic fungicides are very important. Hot benomyl dips and borate degrade spore germination and reduce harmful effects of C. goleosporioides (Kim et al., 2007). However, severe harmful effects and environmental problems arise as a result of fungicides. These problems give a new approach towards the use of environmental friendly plant products that can retard fungal pathogens (Javaid and Akhtar, 2015). Because of fewer harmful effects of natural products on the environment, they are assumed to be good substitutes to synthetic fungicides (Pawar, 2011; Javaid et al., 2015).

Datura metel (family Solanaceae) is an important medicinal plant. It is well known for its insecticidal, herbicidal, antifungal, antibacterial, anticancer, antiinflammatory and antirheumatoid activity (Monira and Munan, 2012; Hossain et al., 2013). D. metel contains flavonoids, phenols, tannins, saponins and sterols as major phytoconstituents (Donatus and Ephraim, 2009). Therefore, the present study was designed to evaluate the antifungal potential of different parts of $D$. metel against $C$. gloeosporioides.

\section{MATERIALS AND METHODS}

Leaves, roots and seeds of $D$. metel were collected from Railway Road Sheikhupura, Punjab, Pakistan. Different plant parts were thoroughly washed and completely dried at $35^{\circ} \mathrm{C}$ and stored in polythene bags. The culture of C. gloeosporioides was isolated from the diseased mango plant on $2 \%$ malt extract agar (MEA) medium.

\section{Antifungal bioassay}

One hundred grams of dried leaves, seeds and roots of D. metel were soaked in $250 \mathrm{~mL}$ methanol for a week at room temperature; afterwards, the soaked materials were filtered through autoclaved muslin cloth. The extract was then allowed to evaporate until volume was reduced to $5 \mathrm{~g}$. This plant extract was further diluted by adding $55 \mathrm{~mL}$ of distilled water to make $20 \%$ stock solution. Malt extract agar (2 g 100-1 destilledwater) was prepared in $250 \mathrm{~mL}$ flask by adding the required amount of MEA in 51, 52.5, 54, 55.5, 57 and $60 \mathrm{~mL}$ of distilled water. This medium was autoclaved at $121^{\circ} \mathrm{C}$ for 30 minutes. Five concentrations viz. 3\%, 2.5\%, 2\%, 1.5\% and $1 \%$ of leaves, roots and seeds were prepared. For preparation of these concentrations 9, 7.5, 6, 4.5 and $3 \mathrm{~mL}$ stock solutions were added to $51,52.5,54,55.5,57 \mathrm{~mL}$ of MEA, respectively, to make a final volume up to $60 \mathrm{~mL}$. Chloromycetin $\left(250 \mathrm{mg} \mathrm{L}^{-1}\right)$ was added in each concentration to avoid bacterial contamination and $20 \mathrm{~mL}$ of each concentration was poured in $9 \times 9 \mathrm{~cm}$ sterilized Petri plates. All Petri plates were inoculated by $C$. gloeosporioides with sterilized cork borer from the tips of two-week old fungal culture and tightly packed. All the concentrations were replicated three times. After 7 days, fungal growth diameter was measured in centimeters by taking average of three diameters at right angle of each colony. Percentage growth inhibition of the fungal colonies was determined by using the formula:

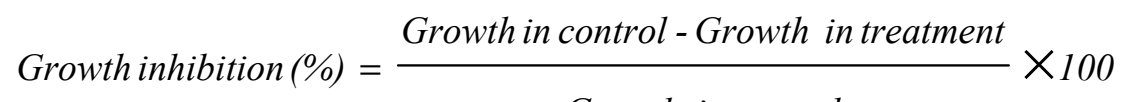

Growth in control 


\section{Phytochemical analysis}

Biochemical constituents of Datura metel seeds were evaluated by phytochemical analysis of the methanolic extract. Standard techniques and methodologies of Edeoga et al. (2005), and Parekh and Chanda (2007) were followed for these tests.

\section{In vitro bioassay with isolated fractions}

The most effectual plant part (seed) was selected for bioassay-guided fractionation to check its antifungal potential against C. gloeosporioides. One hundred and fifty grams powdered seeds of $D$. metel were extracted with $400 \mathrm{~mL}$ methanol. This extract was evaporated on a rotary evaporator and further portioned with various organic solvents in increasing order of polarity including $n$-hexane, chloroform, ethyl acetate and $n$-butanol (Jabeen et al., 2013). This partitioning resulted in the gummy mass of $n$-hexane $(1.56 \mathrm{~g})$, chloroform $(2.66 \mathrm{~g})$, ethyl acetate $(2.23 \mathrm{~g})$ and $n$-butanol $(1.86 \mathrm{~g})$. All the four fractions were serially diluted to check their bioactivity against the target fungus by following the protocol of Sherazi et al. (2016).

\section{GC-MS Analysis}

The chloroform fraction of the methanolic seed extract of $D$. metel was found the most effective in a previous assay hence it was selected for GC-MS analysis. This fraction was separated through HP-5MS capillary column $(30 \mathrm{~m} \times 0.25 \mathrm{~mm} \times 1.0 \mu \mathrm{L})$ by applying the following temperature program; $40{ }^{\circ} \mathrm{C}$ for $5 \mathrm{~min}, 40-47^{\circ} \mathrm{C}$ at $2{ }^{\circ} \mathrm{C} \mathrm{min}-1$, $70{ }^{\circ} \mathrm{C}$ for $2 \mathrm{~min}, 70120{ }^{\circ} \mathrm{C}$ at $3{ }^{\circ} \mathrm{C} \mathrm{min}^{-1}$, $120-150{ }^{\circ} \mathrm{C}$ at $5{ }^{\circ} \mathrm{C} \mathrm{min}{ }^{-1}, 150-220{ }^{\circ} \mathrm{C}$ at $10{ }^{\circ} \mathrm{C} \mathrm{min}-1$ and then $220{ }^{\circ} \mathrm{C}$ for $2 \mathrm{~min} .280{ }^{\circ} \mathrm{C}$ was set as transfer line temperature. Mass detector conditions were: electronic impact (EI) mode at 70 ev; scanning rate 2.88 scan $\mathrm{S}-1$; temperature source: $200{ }^{\circ} \mathrm{C}$ : mass scanning range: $\mathrm{m} / \mathrm{z} 29-540$; helium gas at $1.0 \mathrm{~mL} \mathrm{~min}^{-1}$ (Waheed et al., 2016). The constituents of volatile components were identified after comparison with the computer data system library (NIST 98) attached to the GC-MS instrument and document.

\section{Statistical analysis}

All the data were statistically analyzed by using analysis of variance (ANOVA) followed by Duncan's Multiple Range Test at 5\% level of significance with the aid of the computer software COSTAT.

\section{RESULTS AND DISCUSSION}

In the present study, the antifungal potential of $D$. metel was assessed against C. gloeosporioides. All the applied concentrations of $D$. metel caused significant reduction in radial growth of the test fungus (Figure $1 \mathrm{~A}$ and B). The methanolic seed extract of D. metel was found to be highly effectual in in vitro bioassay as all the applied concentrations significantly retarded the radial growth of C. gloeosporoides. Both the higher concentrations viz. $3 \%$ and $2.5 \%$ caused maximum reduction in the growth of the test fungus by $76 \%$ and $80 \%$, respectively. The methanolic extract of roots of $D$. metel was also found effective as there was $35 \%$ inhibition in test fungus growth in the $1.5 \%$ concentration. The methanolic leaf extract of $D$. metel was found to be less effective in the in vitro bioassay. Shahnaz et al. (2010) investigated that D. metel extracts successfully reduced the growth of Macrophomina phaseolina and Rhizoctonia solani. In a similar study, Rinez et al. (2013) suggested that D. metel extracts can be used as a fungicide to control Fusarium oxysporum.

The results of the phytochemical analysis showed that phlobatanins, flavonoids, terpenoids, alkaloids and coumarins were present in the methanolic extract of D. metel seeds (Table 1). Previously, Monira and Munan (2012) reported that alkaloids, flavonoids and tannins are present in $D$. metel. Sarkiyayi et al. (2013) suggested that the antifungal activity D. metel might be due to the presence of alkaloids, terpenoid, steroids, flavonoid, triterpenes, phenolic and tannin compounds. 


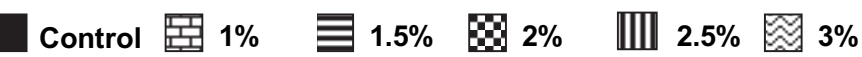

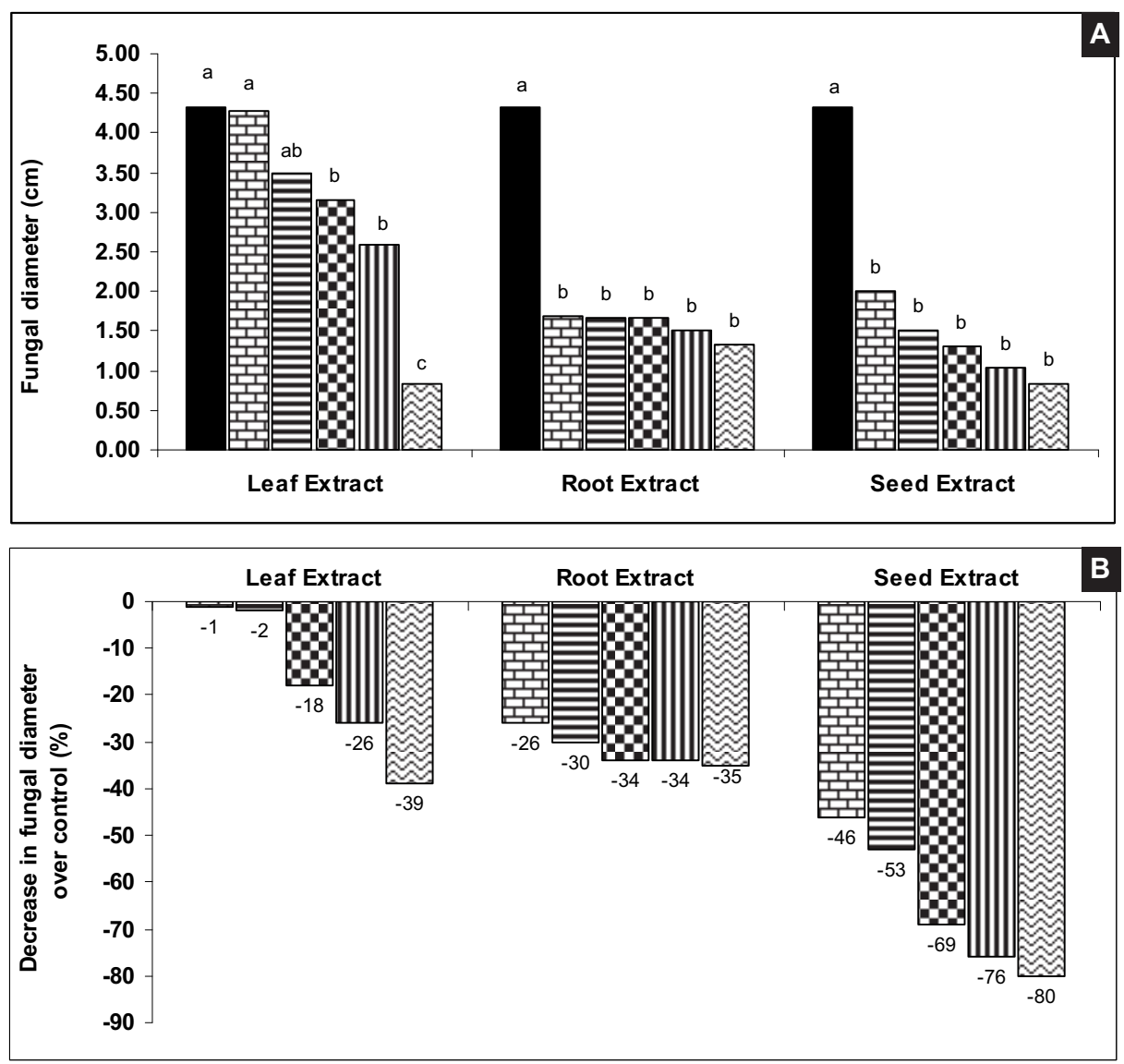

Values with different letters at the top show significant difference $(\mathrm{P} \leq 0.05)$ as determined by the DMR Test.

Figure 1 - Effect of methanolic leaf, root and seed extracts of D. metel on growth of C. gleosporioides.

Table 1 - Phytochemical analysis of the methanolic extract of D. metel seeds

\begin{tabular}{|l|l|c|}
\hline \multicolumn{1}{|c|}{ Phytochemical } & \multicolumn{1}{|c|}{ Indication } & Results \\
\hline Glycosides & No brown color appears \\
\hline Saponins & No frothing appears & -ve \\
\hline Phlobatanins & Formation of Red ppt. occur & $+\mathrm{ve}$ \\
\hline Terpenoids & Ring formation occur & $+\mathrm{ve}$ \\
\hline Flavonoids & Yellow color appears & $+\mathrm{ve}$ \\
\hline Alkaloids & Orange color appears & $+\mathrm{ve}$ \\
\hline Coumarins & Color appears under UV & $+\mathrm{ve}$ \\
\hline Tannins & & -ve \\
\hline
\end{tabular}

The in vitro bioassay with isolated organic fractions showed that the chloroform fraction of the methanolic seed extract of $D$. metel proved better than other fractions, namely $n$ hexane, $n$-butanol and ethyl acetate, at retarding the growth of the mycelial mass of $C$. gloeosporioides as it caused 53\% reduction in fungal biomass (Figure 2). This effective fraction was subjected to GC-MS analysis for separation and identification of bioactive constituents (Figure 3).

Six compounds were identified in the GC-MS analysis from the chloroform fraction of the methanolic seed extract (Table 2). As seeds are rich in fatty acid, the major proportion of this fraction consists of fatty acid. Saturated fatty acids such as octadecadienoic acid, $n$-hexadecanoic acid, hydrocarbons e.g. o-xylene and phytol were identified in the chloroform fraction of $D$. metel. 


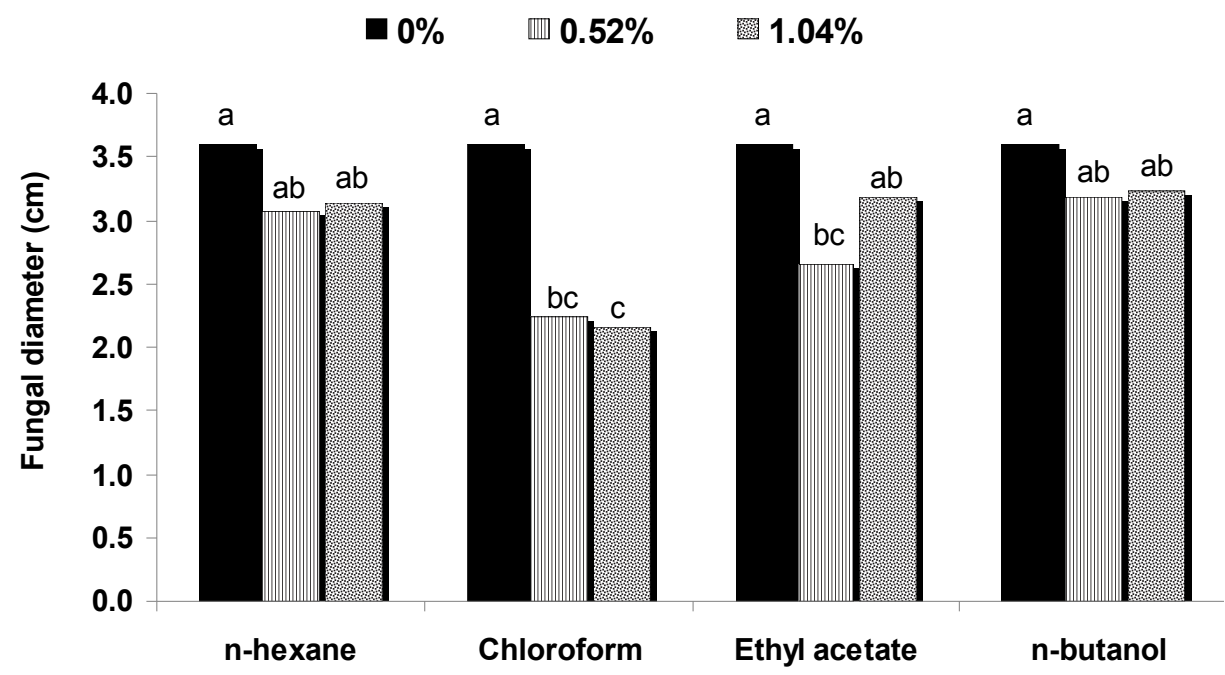

Values with different letters show significant difference as determined by the DMR test.

Figure 2 - Effect of different concentrations of isolated fractions from the D. metel methanolic seed extract on the in vitro growth of C. gloeosporioides.

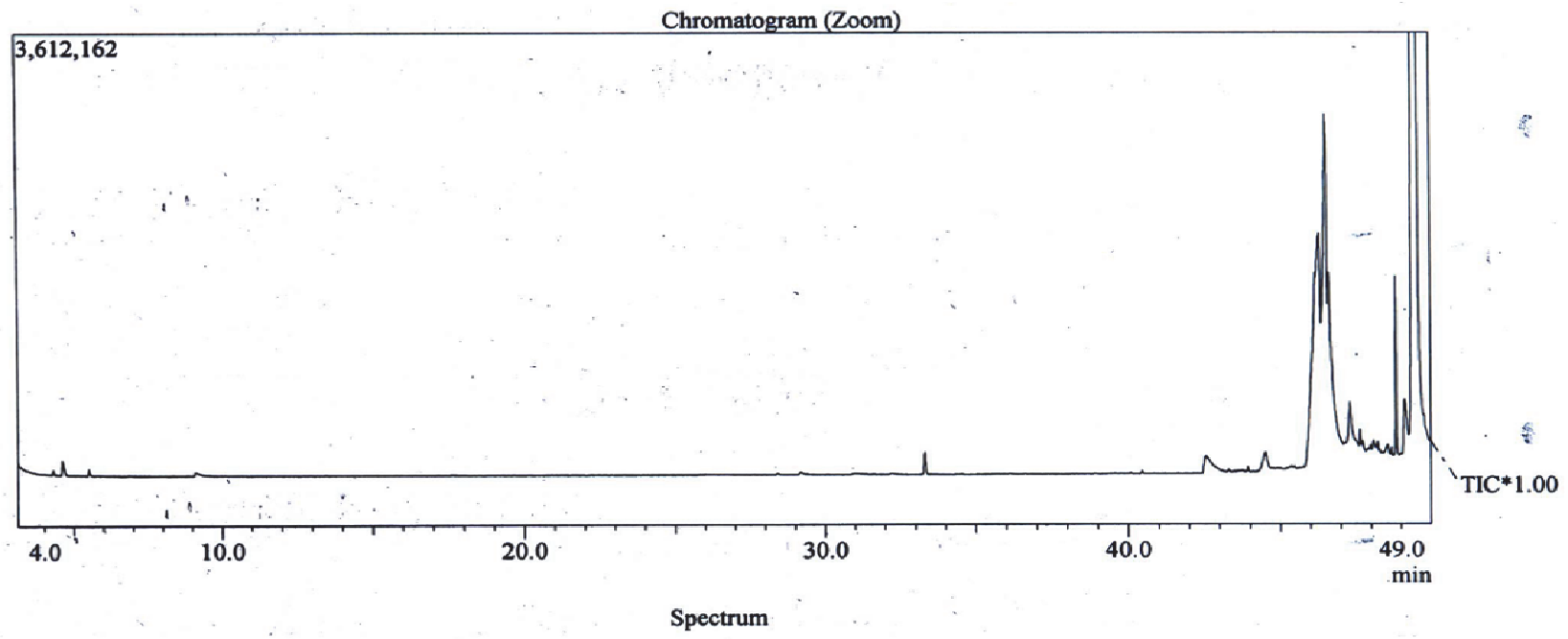

Figure 3 - GC-MS Chromatogram of chloroform extracts from D. metel seeds.

Table 2 - GC-MS analysis of the chloroform extract of D. metel seeds

\begin{tabular}{|c|l|c|c|c|}
\hline Sr. \# & \multicolumn{1}{|c|}{ Compound name } & Chemical formula & $\begin{array}{c}\text { Molecular } \\
\text { weight }\end{array}$ & $\begin{array}{c}\text { Retention time } \\
\text { (min) }\end{array}$ \\
\hline 1 & Cyclohexanol & $\mathrm{C}_{10} \mathrm{H}_{18} \mathrm{O}$ & 154 & 33.317 \\
\hline 2 & o-Xylene & $\mathrm{C}_{8} \mathrm{H}_{10}$ & 106 & 4.608 \\
\hline 3 & Phytol & $\mathrm{C}_{20} \mathrm{H}_{40} \mathrm{O}$ & 296 & 44.517 \\
\hline 4 & Octadecanoic acid & $\mathrm{C}_{18} \mathrm{H}_{36} \mathrm{O}_{2}$ & 284 & 47.300 \\
\hline 5 & Oleic acid & $\mathrm{C}_{18} \mathrm{H}_{34} \mathrm{O}_{2}$ & 282 & 49.117 \\
\hline 6 & $n$-Hexadecanoic acid & $\mathrm{C}_{16} \mathrm{H}_{32} \mathrm{O}_{2}$ & 256 & 49.567 \\
\hline
\end{tabular}

$n$-hexadecanoic acid is a highly bioactive compound and Abubacker and Deepalakshmi (2013) stated that the methyl ester of hexadecanoic acid isolated from leaves of Annona muricata proved to have extreme antifungal potential against Alternaria solani, Aspergillus fumigatus and Penicillium chrysogenum. A flavonoid, Cyclohexanol was also identified in the GC-MS analysis of D. metel 
seed extract that is known to have active antimicrobial potential (Hussain et al., 2014). Phytol, a diterpene monosaturated alcohol (drug), was also found in the seeds of $D$. metel. The antimicrobial potential of this important drug has been studied by many researchers as Rajab et al. (1998) studied the antimycobacterial potential of phytol. Likewise, Inoue et al. (2005) also assessed the antimicrobial activity of phytol against Staphylococcus aureus. One of the major bioactive compound oleic acid was also found in the present investigation. Abubacker and Devi (2014) reported that oleic acid has antifungal potential against various phytopathogenic fungi such as Colletotrichum fulcatum, Rhizoctonia solani and Fusarium oxysporum.

The present study concludes that the methanolic seed extract of $D$. metel is highly effective against $C$. gloeosporioides, especially the chloroform sub-fraction of this extract, which contains potent antifungal agents. Fatty acids and other compounds present in this sub-fraction might be responsible for antifungal activity.

\section{REFERENCES}

Abubacker M.N., Deepalakshmi T. In vitro Antifungal potentials of bioactive compound methyl ester of hexadecanoic acid isolated from Annona muricata Linn. leaves. Biosci Biotechnol Res Asia. 2013;10:879-84.

Abubacker M.N., Devi P.K. In vitro antifungal potentials of bioactive compound oleic acid, 3-(octadecyloxy) propyl ester isolated from Lepidagathis cristata Willd. (Acanthaceae) inflorescence. Asian Pac J Trop Dis. 2014;7:826-9..

Edeoga H.O. et al. Phytochemical constituents of some Nigerian medicinal Plants. Afr J Biotechnol. 2005;4:685-8.

Donatus EO., Ephraim CI. Isolation, characterization and antibacterial activity of alkaloid from Datura metel Linn leaves. Afr J Pharma Pharmacol. 2009; 3(5): 277-281.

Ghafoor A. et al. Determinants of mango export from Pakistan. J Agric Res. 2010;48:105.

Hossain M.A. et al. Gas chromatography-mass spectrometry analysis and total phenolic contents of various crude extracts from the fruits of Datura metel L. J Taibah Univ Sci. 2013;7:209-15.

Hussain H.T. et al. Stereostructure, antimicrobial and cytotoxic activity of cyclo-hexene, cyclohexanol and pyridine derivatives synthesized from chalcones. Inter J Pharm Sci Res. 2014;5:2084-94.

Inoue Y. et al. Biphasic effects of geranylgeraniol, teprenone, and phytol on the growth of Staphylococcus aureus. Antimicrob Agents Chemother. 2005;49:1770-4.

Jabeen K. et al. Antifungal activity of Azadirachta indica against Alternaria solani. J Life Sci Technol. 2013;1:89-92.

Jat B.L., Sharma P., Gour H.N. Production of enzymes and culture filtrates by Colletotrichum gloeosporioides Penz. causing banana fruit rot. Proc Nat Acad Sci India Section B: Biol Sci. 2013;83:177-80.

Javaid A., Akhtar R. Antifungal activity of methanolic root extract of Withania sommnifera against Fusarium oxysporum f. sp. cepae. African J Tradit. 2015;12:22-7.

Javaid A. et al. Management of Macrophomina phaseolina by extracts of an allelopathic grass Imperata cylindrica. Pakistan J Agric Sci. 2015; 15:37-41.

Kim Y. et al. Antioxidant phytochemical and fruit quality changes in mango (Mangifera indica L.) following hot water immersion and controlled atmosphere storage. Food Chem. 2007;105:1327-34.

Monira M.K., Munan S.M. Review on Datura metel: A potential medicinal plant. Glob J Res Med Plants Indig Med. 2012;1:123-32.

Pandey A. et al. In Vitro Studies for resistance to anthracnose disease (Colletotrichum gloeosporioides Penz.) in different mango hybrid seedlings. Inter J Fruit Sci. 2012;12:390-401.

Parekh J., Chanda S.V. In vitro antibacterial activity and phytochemical analysis of some Indian medicinal plants. Turk J Biol. 2007;3:53-8. 
Pawar B.T. Antifungal activity of some stem extracts against seed-borne pathogenic fungi. J Phytol. 2011;12:49-51.

Rajab M.S. et al. Antimycobacterial activity of (E)-phytol and derivatives: a preliminary structure-activity study. Planta Med. 1998;64:2-4.

Rinez A. et al. Antifungal activity of Datura metel L. organic and aqueous extracts on some pathogenic and antagonistic fungi. Afr J Microbiol Res. 2013;16:1605-12.

Saju K.A. et al. Yield loss of large cardamom (Amomum subulatum Roxb.) due to Colletotrichum blight in Sikkim. J Spices Arom Crop. 2013;22:215-8.

Sarkiyayi S. et al. Comparative analysis of nutritional and anti-nutritional contents of some varieties of mango (Mangifera indica) in Kaduna Metropolis-Nigeria. Res J Appl Sci Eng Technol. 2013;5:2042-4876.

Shahnaz D. et al. Comparative effect of plant extracts of Datura alba Ness and Cynodon dactylon (L.) Pers., alone or in combination with microbial antagonists for the control of root dis ease of cowpea and okra. Pakistan J Bot. 2010;42:1273-9.

Sherazi A.Z. et al. Management of Ascochyta rabiei (Pass). Lab by Chenopodium album L. extracts. Planta Daninha. 2016;34:675-680.

Tahir W.A. et al. An analysis of the effectiveness of extension work conducted by public sector with special reference to mango in the southern Punjab, Pakistan. Pakistan J Agric Sci. 2012;49:229-32.

Waheed N. et al. Biopesticidal activity of Calotropis procera L. against Macrophomina phaseolina. Afr J Tradit Complement Altern Med. 2016;13:163-167. 